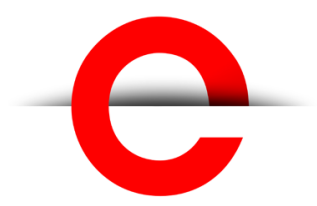

U T S

e PRES S
International Project

Management

Association Research

Conference 2017

2-4 November 2017 (c) 2018 by the author(s). This is an Open Access article distributed under the terms of the Creative Commons Attribution 4.0 International (CC BY 4.0) License (https:// creativecommons.org/licenses/ by/4.0/), allowing third parties to copy and redistribute the material in any medium or format and to remix, transform, and build upon the material for any purpose, even commercially, provided the original work is properly cited and states its license.

Citation: Kim, J. 2018. Impact of Project Managers' Positive Ways of Thinking on Project Success - A Case Study of a CSR Project of Incheon Bridge Company. International Project Management Association Research Conference 2017. UTS ePRESS, Sydney: NSW, pp. 1-11. https:// doi.org/10.5130/pmrp. ipmarc2017.5684

Published by UTS ePRESS I http://pmrp.epress.lib.uts. edu.au
CONFERENCE PAPER

\section{Impact of Project Managers' Positive Ways of Thinking on Project Success - A Case Study of a CSR Project of Incheon Bridge Company}

\section{Jung-hyun Kim}

Incheon Bridge Co., Ltd., 1113-70, Unnam-dong Jung-gu Incheon, 400812, Republic of Korea

*Corresponding author: Jung-hyun Kim. fairy0jhanaver.com

Name: International Project Management Association Research Conference 2017

Location: Incheon, Republic of Korea

Dates: $2^{\text {nd }}$ to $4^{\text {th }}$ November 2017

Host Organisation: IPMA-Korea

DOI: https://doi.org/10.5130/pmrp.ipmarc2017.5684

Published: 08/06/2018

"Life is one big project, the trick is in managing it" (Maylor 2010). Life is one big project that draws upon various projects filled with hopes and dreams. Human beings want to realize their dreams through Project Management (PM). PM has been developed and spread around the world for decades, with international organizations such as IPMA founded as a way to realise uncertain future possibility as concrete reality (Bredillet et al. 2014).

However, existing studies of PM present several issues, because their focus is only on empirical studies of management methodologies to achieve goals, i.e. analysing the outcome of substantive phenomena (Smyth \& Morris 2007). This is largely due to a dependence outcome. A lack of consideration of the project manager's perception is the cause of the phenomena (Kim 2015). Because a project manager is, in fact, the principal actor who plans, executes, and manages an overall project, the non-inclusion of the project manager's perception has caused the outcome of PM to fall short of expectations and has inhibited its growth (Bredillet et al. 2014; Kim 2015).

To overcome the factors that limit the growth of PM and then to resolve issues, it is necessary to include the project manager's perception in the management domain and study the manager's ways of thinking along with the existing empirical management methodologies. 
First, the study of the project manager's way of thinking can complement existing empirical studies of management methodologies, which have presented limitations in fulfilling the developmental desires of project managers (Ahlemann et al. 2012; Ellmann et al.2007). Second, recently the definition of project concept has expanded to include project managers' worldviews and their ways of thinking, but this is still in the initial stage of development. In that sense, the newly developing concept can be a basis for overcoming the inhibiting factors of PM and resolving relevant issues (Ellmann \& Månsson 2009; Kim 2015). Third, the new approach can contribute to expansion of perspective and the sustainability of PM by embracing a more multi-dimensional and comprehensive thinking. This can be viewed as an entire process, apart from existing empirical management methodologies which are dependent mostly on the outcome of project phenomena (O'Leary \& Williams 2013; Söderlund 2003; Kim 2015).

Based on the needs described above, this paper uses a literature review on human perception to identify the positive way of thinking that a project manager should have, and the impact of ways of thinking on project success. This paper seeks to highlight the importance of a project manager's way of thinking through the case study of Incheon Bridge's Corporate Social Responsibility (CSR) Project.

\section{Characteristics of the CSR Team of Incheon Bridge Company}

Incheon Bridge is connecting "Yeongjong Island, where Incheon International Airport is located, to Songdo International Business District", with the overall length of $21.4 \mathrm{~km}$ (Incheon Bridge Co., Ltd. 2018). Incheon Bridge Co., Ltd. manages the Incheon Bridge Project as a single project, and yet it embraces three projects which are financing, construction, and operation and maintenance (Kim 2015).

Incheon Bridge Co., Ltd. organized the CSR Team in 2015 with the intention of assuming full corporate social responsibility by interacting with local communities. The team comprises six people (three men and three women). According to a division of work based on PM methodologies, each member of the team is a project manager who is involved in planning, execution, and monitoring of their respective responsibilities about CSR.

\section{Incheon Bridge Company's CSR Projects}

Incheon Bridge Company's CSR activities can be largely divided into regular and non-regular projects. The Animal Sanctuary, created to promote a sense of empathy for animals among local residents, and the Therapeutic Horsemanship Centre, designed to improve the quality of life of mentally and physically challenged people, are permanent projects. The Animal Sanctuary (locally called Dodam Dodam Dongmul Nuri) of Incheon Bridge Company offers a shelter for animals in crisis, such as those who have been abandoned or abused, to ensure their happiness, comfort, and activity. The sanctuary offers animal welfare education for local elementary school students and other local community groups, and allows people to volunteer, be a part of the healing process of the injured animals, and share joys and sorrows. The Incheon Bridge Therapeutic Horsemanship Centre helps mentally and physically challenged children and teenagers improve their cognitive, social, and physical health through activities with horses. In addition, local residents and employees of Incheon Bridge Company volunteer at the Therapeutic Horsemanship Centre to provide love and care.

The company is also involved in a variety of CSR activities, including the annual kimchi sharing event organized by employees, the Donation of Mufflers of Love event, in which 
employees and their families give hand-made mufflers to the disadvantaged, free legal counselling services for local residents, local tideland preservation activities, and an orchestra comprised of mentally and physically challenged people.

The CSR projects of Incheon Bridge Company are great examples of how a project manager's ways of thinking influences project success because, despite the entire process of planning, execution, and management following the PM methodology, the projects' potential (purpose and goal) is not always matched by their practicality (outcome).

\section{Literature Review}

Albert Einstein overthrew the Newtonian world view that dominated western thinking for two hundred years, causing a paradigm shift to the new science of the 20th century. Through the statement "We cannot solve our problems with the same thinking we used when we created them," Einstein underscored the importance of ways of thinking. In addition to Einstein, leaders of the era that led innovation for the growth of human community studied human perception to find how ways of thinking can help to improve and develop a given situation. Such movements can also be found in the PM domain.

IPMA's Individual Competence Baseline (ICB) is used as to develop the individual competence of managers and enhance project outcomes (IPMA 2018). Changes in the competence elements of the ICB and their breakdown are indicative of the concern about reflecting manager perception in PM. The following table tracks ICB's changes in the breakdown of competence elements and the elements related to perception.

Table 1 Changes in elements related of perception in various versions of IPMA's ICB

\begin{tabular}{|c|c|c|c|}
\hline Classification & ICB 2.0 (1999) & ICB 3.0 (2006) & ICB 4.0 (2016) \\
\hline $\begin{array}{l}\text { Breakdown of } \\
\text { competence } \\
\text { elements }\end{array}$ & $\begin{array}{l}\text { 1) Knowledge \& } \\
\frac{\text { experience }}{\text { 2) Additional }} \\
\text { elements }\end{array}$ & $\begin{array}{l}\text { 1) Contextual } \\
\text { competences } \\
\text { 2) Behavioural } \\
\text { competences } \\
\text { 3) Technical } \\
\text { competences }\end{array}$ & $\begin{array}{l}\text { 1)Perspective } \\
\text { competences } \\
\text { 2)People } \\
\frac{\text { competences }}{\text { 3)Practice }} \\
\text { competences }\end{array}$ \\
\hline No. of elements & 42 & 46 & 29 \\
\hline $\begin{array}{l}\text { No. of elements } \\
\text { related of } \\
\text { perception }\end{array}$ & 1 & 6 & 3 \\
\hline $\begin{array}{l}\text { Percentage of } \\
\text { elements related } \\
\text { of perception }\end{array}$ & $2.38 \%$ & $13.04 \%$ & $10.34 \%$ \\
\hline
\end{tabular}

- Looking at the changes in the competence elements, there was only one element related to perception in the ICB 2.0, but this number increased to six in version 3.0, and then went down to three in version 4.0. But in the ICB 4.0, the perceptual aspect was deepened by the addition of self-reflection, a philosophical element.

- The percentage of elements related to perception in the overall competence elements is over $10 \%$ in ICB versions 3.0 and 4.0. Compared to the $2 \%$ in ICB 2.0 , this reflects the deeper consideration given to elements related to perception. 
- Looking at the changes in the breakdown method, what was empirically expressed as knowledge, experience, and behaviour in ICB 2.0 and 3.0 is expanded into perspective and people domains in ICB 4.0.

However, despite changes in the IPMA's ICB, there are limitations in view of a small proportion of the elements related to perception and a lack of in-depth study of managers' ways of thinking. Though managers' ways of thinking clearly have an effective impact on project success, the current PM domain does not consider it a variable, leaving it in a blind spot (Scharmer \& Kaufer 2013). From a philosophical and business perspective dealing with the importance of thinking, this paper seeks to investigate the positive ways of thinking and the process that project managers should use.

\section{Emotional Thinking - Intelligent Thinking - Rational Thinking}

In the branch of epistemology dealing with human perception, much research has been conducted on how human consciousness works, including aspired ways of thinking. Through analytical research into human thinking, the epistemology of the Western philosophical tradition—encompassing the works of René Descartes, David Hume, Immanuel Kant, and Georg Wilhelm Friedrich Hegel—broke down cognitive activities into several stages to explain how human consciousness works.

Hegel perceives our spirit as a phenomenon, and that viewpoint is perceived as a concept (Hegel 1807/1977). Hegel depicts the process by which perception attains truth through experience, stating that consciousness, which starts from sense certainty, undergoes a number of phases including scientific knowledge and rational social consciousness (Hegel 1807/1977). As the source and the first step of consciousness, the senses are important in that they assist with the making information of memory. However, judgment that depends upon the pure subjectivity of the senses can cause errors of perception that can trigger behaviours based solely on partial and superficial aspects of phenomena. Scientific intelligence shows the limits of mistaking the universal concept as the essence of the concept. Thus there is a need to develop a sense of certainty and scientific intelligence that can cause errors of perception in rational thinking through the dialectical movements of consciousness and self-consciousness.

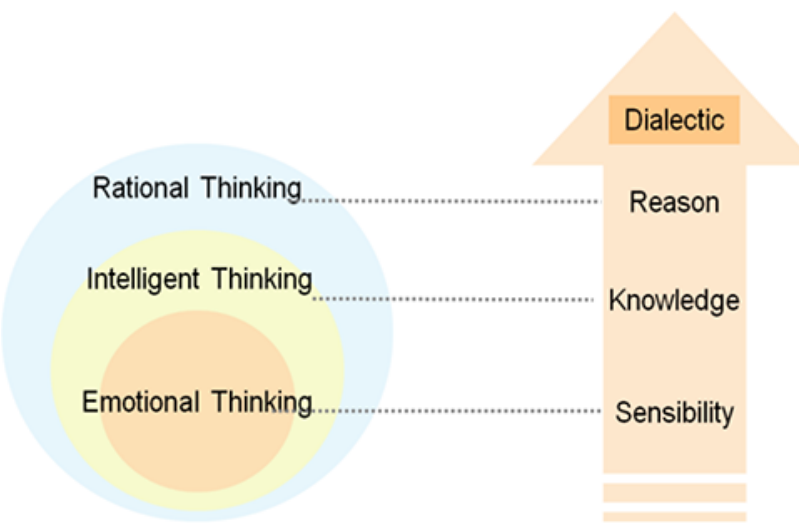

Figure 1 Drawing showing growth from a sense of certainty to scientific knowledge and rational social consciousness 


\section{Open Mind - Open Heart - Open Will}

Professor Scharmer, Dr Senge, and other pioneers in business administration innovation interviewed more than 150 leaders and entrepreneurs over 18 years, and became actively involved in the transformations of various businesses, government organizations, and local communities. What they learned from their work is that "the quality of our results in a system is a function of the perception from which the people in that system operate" (Senge et al 2008). Because social systems show completely different structures and movements depending on people's perception levels, one must change current thinking patterns to create a fundamental change for the emerging future (Scharmer \& Kaufer 2013).

Professor Otto Scharmer proposed the UTheory as a process to change old thought habits. According to the UTheory, the first instrument is an open mind to take in objective and factual information and "suspend old habits of thought"; the second is an open heart to have the "capacity to empathize, to see any situation through the eyes of someone else"; and the third is an open will to have the "capacity to let out the old and let in the new". On that journey, at the bottom of the U, people sense the possibility of the upcoming future, realise it, and acknowledge "presencing” (presence+sensing) (Scharmer \& Kaufer 2013).

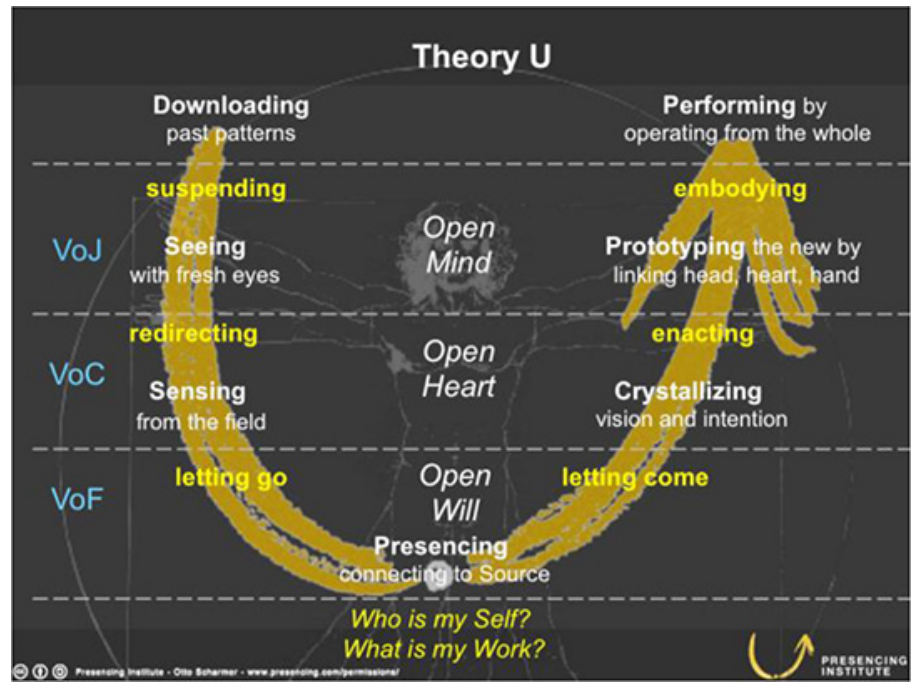

Figure 2 Drawing expressing the U Process of sharing and creating together. Source: Leading from the Emerging Future (From ego-system to Eco-System Economies) by Scharmero \& Kaufer (2013)

Based on the above literature review, this paper made a case study of a CSR project of the Incheon Bridge Company to see how project managers' positive thinking processes and habits of thought are effectively applied in the PM domain, and how they impact project success.

\section{Methodology}

\section{RESEARCH METHODOLOGY}

To understand the impact of a project manager's positive way of thinking, Incheon Bridge Company's CSR project managers were interviewed in order to analyse how they think their perceptions have changed when overcoming difficulties. Based on the results of the interviews, the interviewees' most challenging experiences of the past year were selected, and in-depth 
interviews were conducted, focusing on their perceptions and changes in their thoughts in order to develop a cognitive approach.

\section{Results}

\section{PROBLEMATIC SITUATION}

As stated above, one of the Incheon Bridge Company's CSR projects is operating the Therapeutic Horsemanship Centre to improve the welfare of mentally and physically challenged people in local communities. The CSR team considers taking care of the horses and keeping them healthy to be very important. This is because participants in horsemanship activities need to interact with healthy horses with balanced gaits and good temperaments. However, some employees in the same company denigrated the team by defining the CSR team as doing a petty job, and publicly stated that taking care of horses is just cleaning the horses' manure.

This situation was not only a serious problem for the CSR team, but also for all the other employees. Therefore, every employee perceived the problem seriously, defined it as a "whole company' issue, and put effort into preventing the reoccurrence. Though the problematic situation itself presented a significant challenge to the project managers, the managers were able to overcome the situation through positive ways of thinking. This paper seeks to analyse the entire process with a cognitive approach.

\section{PERCEIVING PROBLEMS - SHIFT IN THOUGHTS - WILL TO CHALLENGE}

The case study showed that the managers' perceptions, which were mainly emotional in the initial stages, began to change as they underwent a process of frustration and introspection through communication with the community, and perceived the problem. Through shifts in thoughts, managers were able to see the problem in terms of universal values, and the shift made managers feel more empathy, then raised the possibility that the community would reach a consensus. The managers' perceptions go to self-reflection from the overall viewpoint of the community. Managers recognised that they are subjects and objects at the same time as a member of community. Afterwards, the managers reached to a point where subjectivity and objectivity became one in a new cognitive aspect. The managers gained the instinctive will to challenge to resolve the problem and drove the projects to success through the processes of setting a goal, carrying out the execution and management plans, and monitoring the outcome.

This paper seeks to present in detail the results of a case study on Incheon Bridge Company's CSR project by looking at how the managers' thoughts have developed after a problem occurred; from (1) perceiving the problem, (2) shift in thoughts, (3) will to challenge, and lastly project success.

\section{PERCEIVING PROBLEMS}

The CSR project managers viewed the operation of the Therapeutic Horsemanship Centre as an important project for enhancing the welfare of mentally and physically challenged people in the local communities, and had worked hard to achieve their goals. They were quite shocked when they first encountered the problem and couldn't get away from emotional thinking. They were experiencing several negative emotions, such as a sense of being betrayed by their colleagues, unpleasant feelings that their hard work had been underestimated, and a sense 


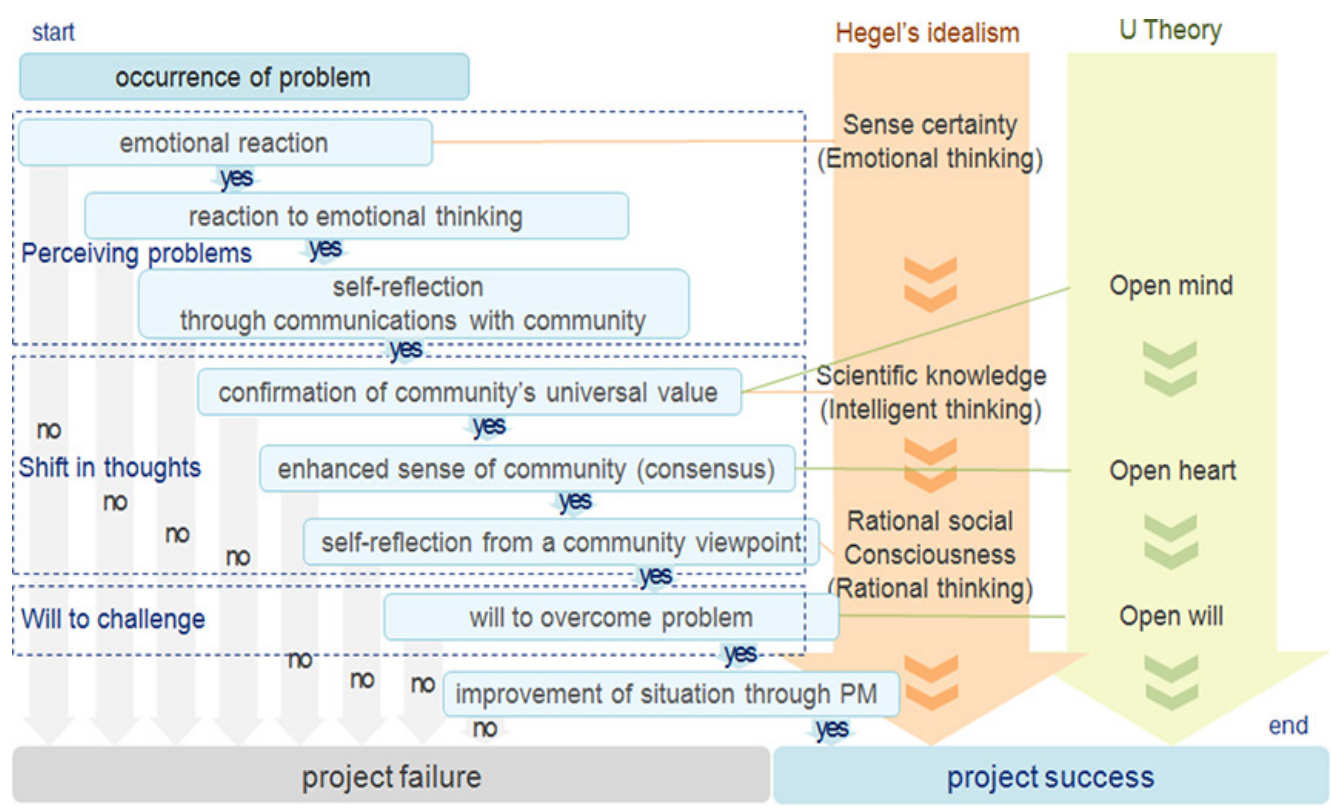

Figure 3 Concept map comparing the results of literature review and case study, and matching perceiving problems, shifts in thoughts, and will to challenge

of being misrepresented, as well as doubts about work they had once been proud of, loss of enthusiasm, anger, sorrow, depression, and resentment.

In general, a project manager can choose one of two courses when faced with a problem. They can either shrink or return to a past behaviour pattern that is sure to end up in failure, or open their hearts and lead change in the direction of future possibilities (Scharmer \& Kaufer 2013). The CSR project managers opted for the second course and expressed themselves in response to the situation.

This led to active communication within the company, including the CSR team. In that process, the project managers became aware of the need for self-reflection, which they were unaware of when their thoughts were emotionally driven. To their surprise, they realized that some members of the community did not share the purpose and values of the CSR project. By perceiving this problem, the managers were able to shift away from the negative emotions about those who had belittled their project to more positive and universal thoughts that a solution was necessary.

\section{SHIFT IN THOUGHTS}

Through a shift in thoughts, the project managers were able to see the problem based on the universal values of the community. This process allowed them to open their hearts to the community domain and gain increased empathy (Scharmer \& Kaufer 2013). The managers examined themselves and realized that, from the community's perspective, they were both subjects and objects as one of community, they were able to reach the stage of rational social consciousness where subjectivity and objectivity become one in a new aspect (Hegel 1807/1977).

In this process, the managers were able to see members of the community as part of a larger picture, which was something that they could not see before. They realized that those who had belittled their project were also members of their own community and that, if they had shared the values and visions of the project, the incident would never have happened in the 
U T S

e P R E S S

first place. The managers couldn't bring empathy through communicating proactively with the community due to their uncertain awareness of purpose, caused by lack of confidence. Also, the managers' will to challenge naturally developed to solve problems and ensure the success of the project through self-reflection based on rational thinking perspectives.

\section{WILL TO CHALLENGE}

The project managers underwent a cognitive process whereby thoughts of negative emotions shifted to positive and universal thoughts, naturally gaining a renewed will to challenge. They were able to start PM afresh and from a new light by resolving immediate problems. Armed with positive thinking, the managers renewed their strategic goals and established an execution and management plan that specified and quantified the goals with procedural content. By managing and monitoring the results of project execution from a time, budget, and goal perspective, they allowed individuals and the entire organization executing the project to share purpose awareness (Kim 2015).

The project managers renewed the goals and purpose of their project to gain empathy from all members of the company community, and, to strengthen purpose awareness, they reorganized their work relationship, connecting upper and lower tasks with goals and execution.

As shown in Figure 4, the new arrangement shows the upper tasks as the goals of the lower tasks, and the lower tasks as the means to achieve the upper tasks. This reorganization allowed project managers to not lose sight of the meaning of each task, and to gain purpose awareness within the larger picture. By highlighting the contribution of ordinary work such as feeding horses and cleaning dogs' ears to overall project success, this approach was designed to increase the managers' pride in work and strengthen purpose awareness (Kim 2015; Scharmer \& Kaufer 2013).

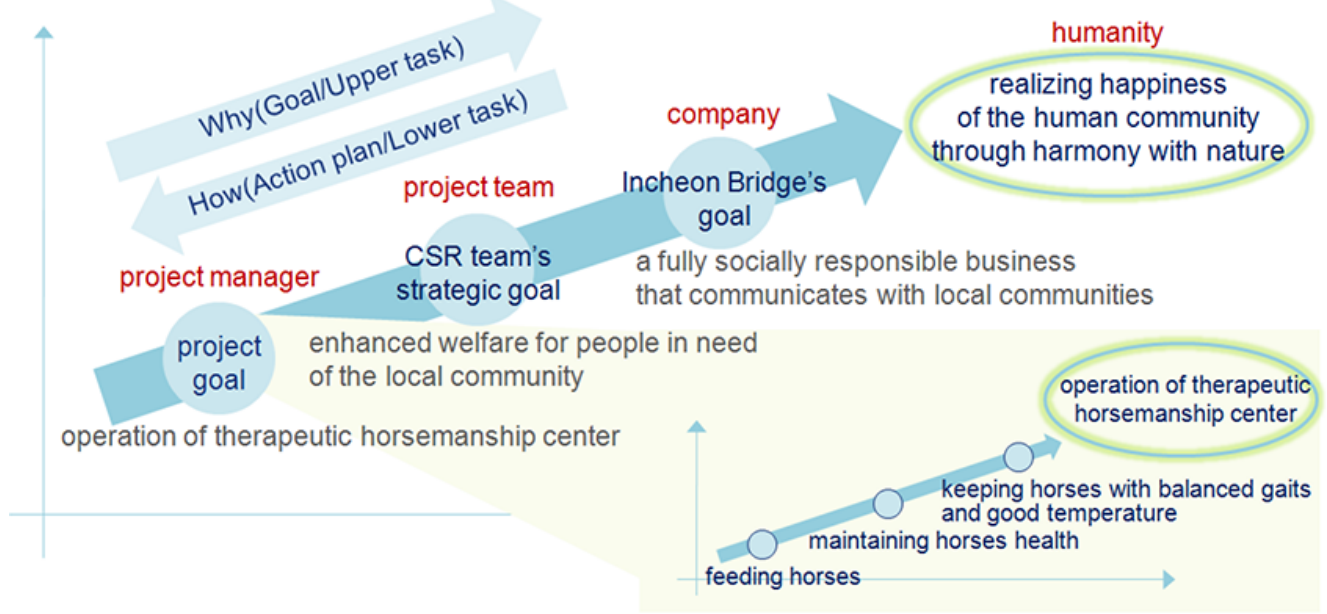

Figure 4 Concept map connecting upper/lower tasks with goals/execution to strengthen awareness of purpose. Source: "A philosophical approach to project management: Project as a phenomenon and the case of Incheon Bridge," (Kim 2015)

Based on strengthened purpose awareness, CSR project managers established a plan for action and management to form a consensus with the company as a community, and monitored the plan and its outcome on an annual, monthly, weekly, and daily basis. By doing 
so, it was found that everyone, including individuals and the organization, could perceive the results successfully.

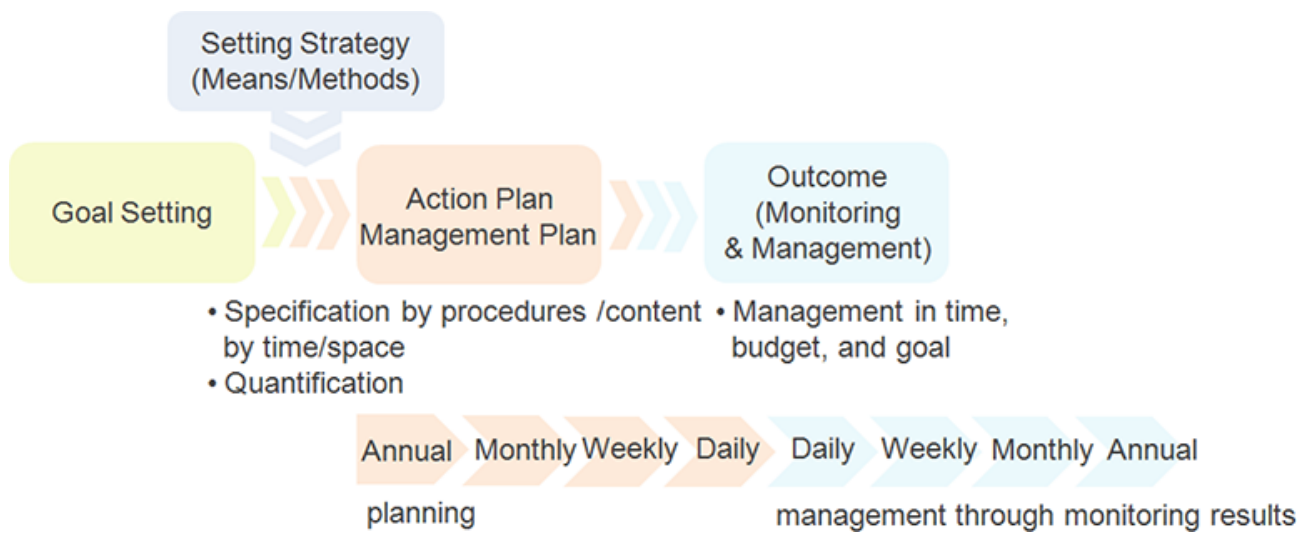

Figure 5 Concept map on PM procedures. Source: “A philosophical approach to PM: Project as a phenomenon and the case of Incheon Bridge," (Kim 2015)

The project managers improved their perception in three steps, which were (1) perceiving a problem, (2) shift in thoughts, and (3) will to challenge, and this led to consensus on project success. While progressing the project systematically, the managers have gained greater pride in their work, and as community members, the more they consented to the project, the higher rate of participation they had. With stronger community support, thousands of students now take part in the animal welfare education programme every year, and quality of life has improved for hundreds of disabled local residents and their guardians through the therapeutic horsemanship programme.

\section{Conclusion}

By introducing the elements related to perception of ways of thinking as a way to project success, the case study of a CSR project of Incheon Bridge Company showed that managers' positive ways of thinking have an effective impact on project success.

The case study showed that the project managers created an opportunity for shifting their thoughts by perceiving problems. They underwent frustration and self-examination as they interacted with the community, changed their thoughts to see the problem based on the community's universal values, and ultimately reached a consensus with the community. The managers reflected upon themselves from the community's viewpoint, reaching a new perspective in which that they were both the subjectivity and objectivity as one of community members, and in that process instinctive will to challenge was triggered to drive the project to success. The key point is the shift in thoughts; this uplifts managers' perceptions to a higher level. Therefore shifting from emotional thinking (depending on sense certainty) to intelligent thinking based on universal values, and rational thinking whereby subjectivity and objectivity become one in the development of a shift in thought perception, a premise f project success (Hegel 1807/1977).

The initial negative, emotional thinking shown by the project managers of the Incheon Bridge Company are realistic problems that anyone can experience when a sudden, unanticipated change occurs while planning, executing, and managing a project. If negative ways of thinking cannot be changed, a project that started off with the goal of developing the human community may lose its original intent, and the journey to success will stop. 
The inclusion of manager perception in the PM domain, which had hitherto been relatively neglected, complements empirical management methodologies. This approach seeks to establish a cognitive foundation for resolving the existing problems of PM, and ultimately to present some directions for enlarging and sustaining the perspectives of PM.

\section{Reference}

Ahlemann, F., El Arbi, F., Kaiser, M. G, \& Heck, A. (2012). A process framework for theoretically grounded prescriptive research in the project management field. International Journal of Project Management, 31 (1), 43-56.

Bredillet, C. N., Tywoniak, S., \& Dwivedula, R. (2014). What is a good project manager? An Aristotelian perspective. International Journal of Project Management, (2010). Blowing hot and cold on project management. Project Management Journal, 41 (3), 4-20 33 (2), 254-266.

Ellmann, S. \& Månsson, E. (2009). Holistic Stakeholder Management: Coping with Stakeholder challenges in the 21st century. IPMA World Congress, Helsinki, Finland: International Project Management Association.

Ellmann, S., Månsson, E., Hübner, R., Domachowski, M. \& Maessen, R. (2007). Multidimensional PM Coping with the new challenges for project managers. IPMA World Congress, Cracow, Poland: International Project Management Association.

Hegel, G. W. F. (1977). The Phenomenology of Sprit. (A. V. Miller, Trans.). Oxford, London: Oxford University Press. (Original work published 1807).

Incheon Bridge Co., Ltd. (2018). Business Introduction. Retrieved from http://www.incheonbridge. $\mathrm{com} /$.

IPMA (International Project Management Association). (2018). IPMA Standards. Retrieved from http://www.ipma.world/individuals/standard/

Kim, S. (2015). A Philosophical Approach to Project Management: Project as a Phenomenon and the Case of Incheon Bridge. IPMA World Congress, Westin Playa Bonita, Panama: International Project Management Association. Procedia Social and Behaviour Science, Vol. 226, 456-462.

Maylor, H. (2010). Project Management (4th ed). Harlow: Financial Times Prentice Hall.

O'Leary, T. \& Williams, T. (2013). Managing the Social Trajectory: A Practice Perspective on Project Management. IEEE Transactions on Engineering Management, 60 (3), 566-580.

Scharmer, O. \& Kaufer, K. (2013). Leading from the Emerging Future (From Ego-system to Eco-System Economies). San Francisco: Berrett-Koehler.

Senge, P., Scharmer, O., Jaworski, J., \& Flowers, B.S. (2008). Presence: Human Purpose and the Field of the Future. New York: Doubleday.

Smyth, H. J. \& Morris, P.W. G. (2007). An epistemological evaluation of research into projects and their management: methodological issues. International Journal of Project Management, 25, 423-436.

Söderlund, J. (2003). Building theories of project management: Past research, questions for the future. International Journal of Project Management, 22 (3), 183-191. 


\section{About the Author}

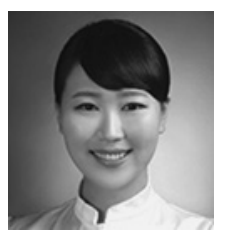

Jung-hyun Kim was born in Seoul and majored in Politics, Theology and minored in Business at Yonsei University, Korea. Kim is a governmentcertified horse riding instructor and a therapeutic horse riding instructor. Now Kim is currently managing various social contribution projects in Incheon Bridge Company, such as animal sanctuary, animal welfare education, and horsemanship activities for mentally/physically challenged people. 